TECTONICS, VOL. 5, NO. 5, PAGES 769-781, SEPTEMBER 1986

MAGNETIC FABRIC IN "UNDEFORMFD" MARINE: CLAYS FROM COMPRESSIONAL ZONES

Catherine Kissel, Eric Barrier and Carlo Laj

Centre des Faibles Radioactivités, Laboratoire mixte CNRS/CEA, Domaine du CNRS, 91190 Gif-sur-Yvette, France.

\section{Teh-Ouei Lee}

Institute of Earth Sciences, Academia Sinica, Taipei, Taiwan, Republic of China.

Abstract. We present the results of magnetic fabric analysis obtained on samples of marine clays from sedimentary sequences in Northwestem Greece and Taiwan, in regions which have been submitted to large scale compressional events. The lithology of the sediments is mainly composed of urmetamorphosed marls, siltstones and sandstones. These formations are folded and faulted at different scales. The magnetic fabric is largely sedimentary. However both at single sites (Taiwan) and regionally (Greece) the magnetic lineation is systematically perpendicular to the main compressive stress $\sigma_{1}$ inferred from previous fault tectonic analysis. This is an indication that the fabric is also partly of tectonic origin. In Northwestern Greece the orientation of the magnetic susceptibility ellipsoid is constant over distances exceeding $200 \mathrm{~km}$, suggesting that the orientation of the principal compressive strain relative to the trend of the main structures has been constant since Lower Oligocene

\section{INIRODUCTION}

During the last few years an increasing nmber of papers have been dedicated to the study of the magnetic fabrics of rocks. It has been demonst rated that the analysis of the shape and orientation of the magnetic susceptibility ellipsoid may give valuable infomation about the fomation and subsequent

Copyright 1986

by the American Geophysical Union.

Paper number 6T0094.

0278-7407/86/006T-0094\$10.00 defornation of a rock. Because magnetic fabric analysis can now be performed very quickly and the techrique is nondestructive, this type of study has gained considerable acceptance among structural geologists and sedimentologists.

Most studies have concerned either sediments or strongly deformed rocks. In the first case it has generally been considered that magnetic fabric results from compaction of the sediments and/or the presence of depositional currents (Rees, 1965; Hamilton and Rees, 1970; Argenton et al., 1975; Elwood, 1979, 1980). In the second the original sedimentary fabric is completely obliterated by the dominating tectonic fabric (Rathore, 1980; Rochette and Vialon, 1984).

A few authors have considered the problem of weakly deformed rocks and how the primary and tectonic fabrics interact in the first stages of deformation (Borradaile and Tarling, 1981; Kligfield et al., 1981, 1983). However, even in these cases, most of the investigated rocks have undergone some degree of metamorphism and have been folded on a large scale, although single samples may appear undeformed.

The purpose of this work is to investigate the anisotropy of the magnetic susceptibility of sediments which, although some compaction may have occurred, appear otherwise to be completely undeformed. The studied formations are composed of unnetamorphosed marine sediments and have been folded and faulted at different scales. The sites are located in Northwestem Greece and the Coastal Range of Taiwan, regions where previous structural geology studies have demonstrated the existence of largerscale compressional tectonics. 


\section{STRUCTURAL SETTING}

All the studied samples have a similar lithology although they have been collected in two different regions. Both in Northwestern Greece and in the Coastal lange of Taiwan the tectonic context is compressive and deformation results from active collision. This is an important feature for the interpretation of the magnetic data. The main structural characteristics of the two zones are outlined below.

\subsection{The Coastal Range of Taiwan}

The active Taiwan orogen results from the collision of the western border of the Philippine Sea plate with the stable continental margin (Suppe, 1981). Both the continental margin and the Philippine Sea plate are deformed in the collision zone. The Luzon volcanic arc, which is built on the oceanic plate, is shortened giving rise to the Coastal Range orogeny.

The basement of the Coastal Range consists of Miocene volcanics of the Tuluanshan formation (Figure 1) including agglomerates, tuffs, tuffaceous sandstones and volcanic conglomerates. The sedimentary formations, overlying the volcanics, are mainly composed of thick terrigeneous sequences of Pliocene and Pleistocene age. These sequences, called the Takangkou formation, consist of alternations of marls and sandstones, with intercalated congloneratic lenses and large olistostromes.

The Coastal Range is separated from the rest of the island by the longitudinal valley oriented $\mathrm{NO20}$ and bounded by an active thrust fault with a minor strike-slip component (Barrier, 1985). The structure of the range is characterized by an "en echelon" fold system marked by elongated outcrops of Tuluanshan fomation (Figure 1). The direction of these fold axes $(040)$ is oblique with respect to the general trend of the chain.

\subsection{Northwestern Greece}

In contrast with the rest of Aegea where a mostly extensional regime has existed since at least the Upper Hiocene, Northwestern Greece has been submitted to a large scale compressive regime.

Three main phases of compressional tectonic activity have been documented since the Upper oligocene. They occurred during the Middle Miocene (Late Burdigalian), the Lower Pliocene and the Lower Pleistocene. The three phases are characterized by a westward migration: during the Middle Miocene the main compressive front (Ionian-Lycian arc) was situated to the East of the Ionian Islands, in the Ionian zone, while the Pliocene and Quaternary phases have mainly affected the Ionian islands (Institut de Géologie et Recherche du soususol - Institut Francais du Pétrole, 1966; Mercier et al., 1979).
This complex tectonic history has resulted in the development of overthrusts, large elongated structures, and symclines and anticlines with horizontal axes, sone of which are over a hundred kilometers in length (Figure 2).

\section{SAMPLING AND EXPERTMENTAL METHZUDS}

In the Coastal Range of Taiwan, the stratigraphy is well defined after the work of Chi et al. (1981). The sanpling has been carried out in the marly layers of the Takangkou formation (sites $03,04,05,06,07$, $09,10,11)$ and in the tuffaceous sandstones of the top of the Tuluanshan formation (sites $01,(2,08$ ). The studied fornations belong either to the Lower Pliocene (namofossils zone $\mathrm{NN} 15$, for sites 01,02 , $03,04,06,07,08,09)$, or to the Lower Pleistocene (nannofossils zone $\mathrm{NN19}$, for sites $05,10,11$ ). Site 12 has been sampled in a synsedimentary slump very near to site 10 .

In mainland Northwestern Greece we have sampled both the Lower to Upper Oligocene flysch sections in Epirus and Akarnania and the Upper Miocene to Upper Pleistocene marine clay formations in the Ionian islands. In Epirus large, faulted folds dominate, while in Akamania their amplitude is smaller and low angle uncomformities are often encountered. Sites were sampled in the flanks of major structures, the horizontal axes of which are aligned along the main regional direction of the belt, such as the Botsara syncline.

In the Ionian islands we have sampled fornations in both the Ionian and Preapulian isopic zones (Brum, 1956). In 7ackinthos and Kephallinia the sites were sampled in structures the axes of which are also parallel to the belt. In Corfu, which belongs entirely to the external Ionian zone, some of the folds do not have a direct regional significance. A more detailed description of the sampled sites in Northwestern Greece can be found in laj et al. (1982) and Kissel et al. (1984, 1985a).

Both in Greece and in Taiwan only fine grained sediments were sampled. Sections too close to major faults were avoided. Only blue grey marls were sampled, because laboratory studies have shown that sediments of this color are not affected by weathering. Drilling and orientation of the cores were done with standard paleomagnetic techniques using an electric drill. The corer is a $25 \mathrm{~mm}$ barrel with a sintered diamond cutting edge cooled by water or compressed air. The cores were cut into individual specimens of $22.5 \mathrm{~mm}$ length.

The susceptibilities were measured with a bridge method with an accuracy of a few percent. Measurements of the anisotropy of the magnetic susceptibility were made with a Digico Anisotropy Delineator modified in the laboratory and using the calibration procedure given by Veitch et al. (1983). Greater stability and overall accuracy of the instrument were achieved through the use of an active 


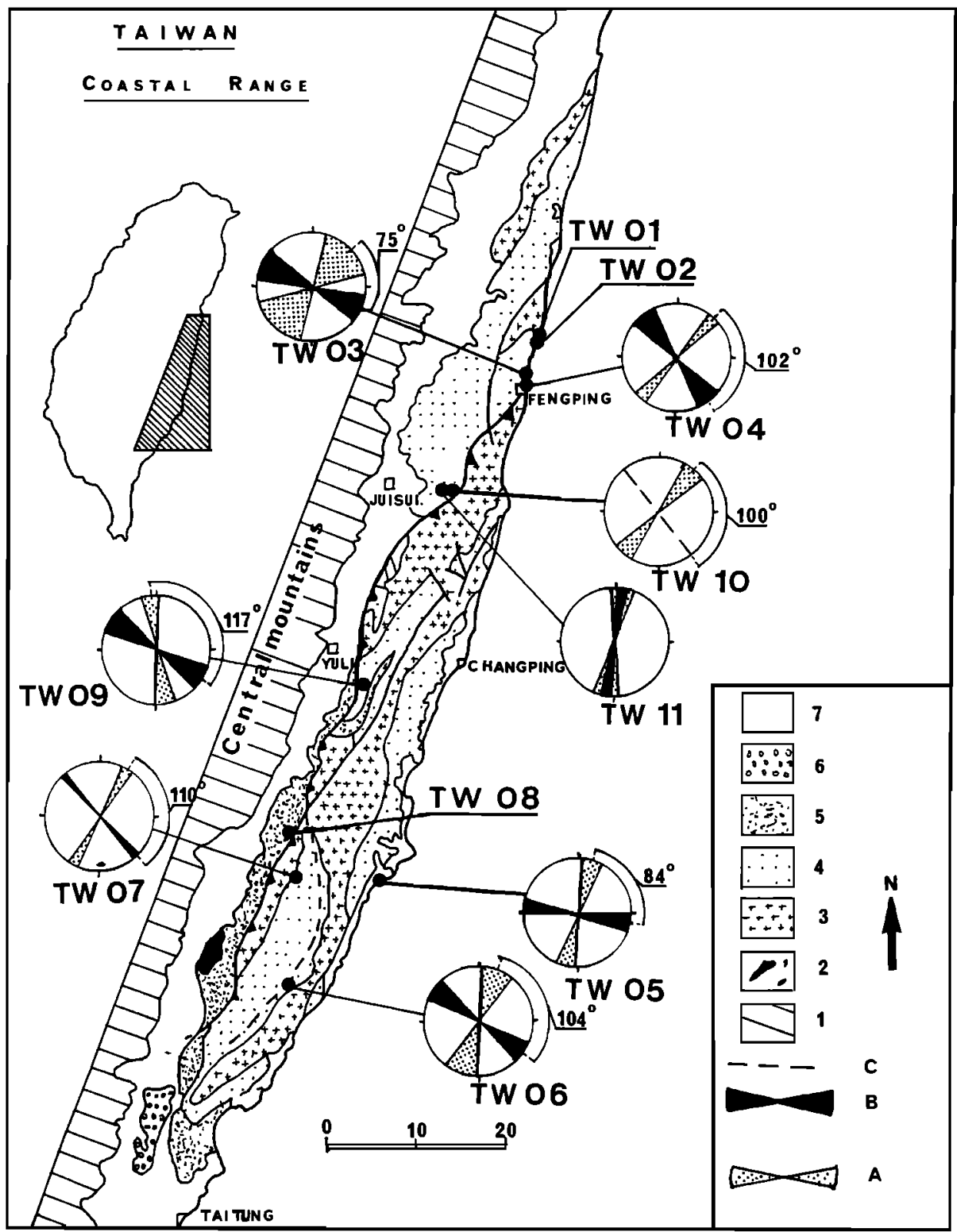

Fig. 1. Schematic geological map of the Coastal Range of Taiwan. 1, Central mountains; 2, blocks of East Taiwan ophiolite; 3, Tuluanshan formation; 4, Takangkou fonmation; 5, Pinanshan conglomerate; 6 , Alluvium. This figure presents the angular relation which exists between the magnetic lineation (A) and the local (B) or the regional (C) stress $\sigma$. The angle between $\mathrm{K}_{1}$ and $\sigma$ direction is indicated close to the circles.

low-pass filter, set at $20-25 \mathrm{cps}$, in series between the amplifier and the computer, as suggested to us by F. Heller in Zurich. Repeated measurements on the same samples yield identical results with an accuracy of about $5^{\circ}$ in direction and a few percent in magnitude. A total of 850 cores were examined.
4. RESULTS

\subsection{Ceneral}

$X$ ray analyses were systematically perfonned on samples from the different sites. Whatever their 


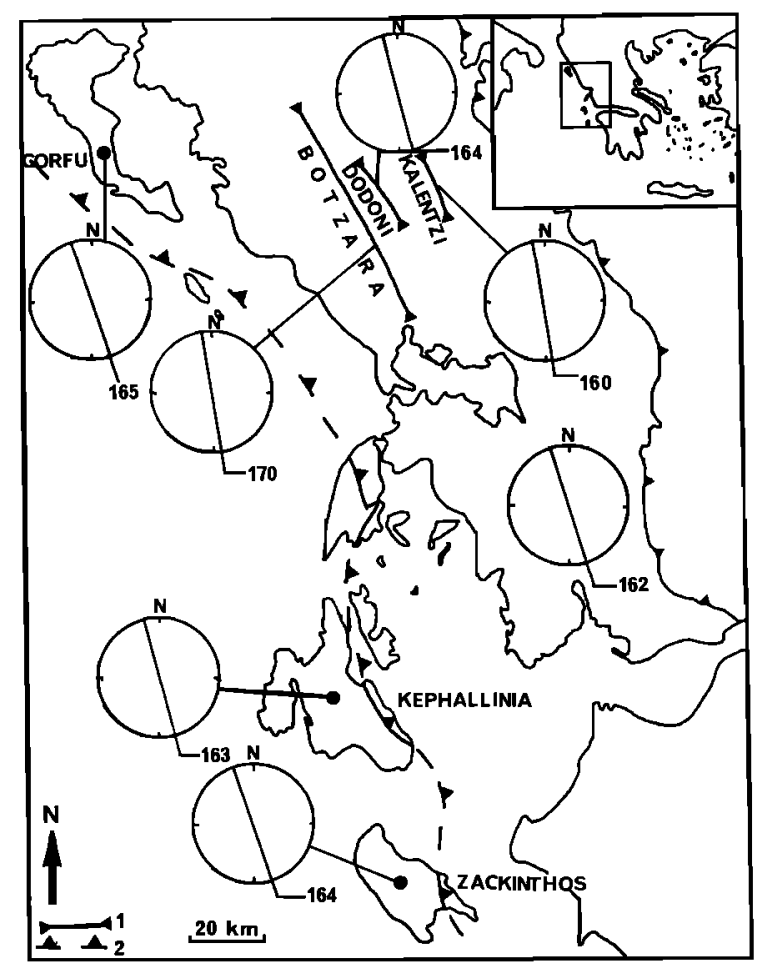

Fig. 2. Schematic map of Northwestem Greece locating few major synclines (curve 1) in Epinus. Thrust (curve 2) of the Ionian zone over the Preapulian Zone. The obtained mean orientations of the magnetic lineation are reported in the circles for each region and they have been calculated using the statistical method described by Westphal (1981).

geographical origin the mineralogy does not show any significant change. The three detrital clays, chlorite, illite and kaolinite dominate with quartz and calcite also present in variable amounts. No evidence of in situ weathering was found.

IRM acquisition experiments up to $1.5 \mathrm{~T}$ indicate that magnetite is the main magnetic carrier. The presence of higher coercivity magnetic mineral was sometimes detected, but in all cases the median destructive field of the saturation IRM was less than $0.3 \mathrm{mI}$ confirming the dominant presence of magnetite.

\subsection{Anisotropy of the Magnetic Susceptibility}

The low-field magnetic susceptibility of a rock is described by a symetric tensor of second rank, which in turn may be visualized as an ellipsoid with principal axes $\mathrm{K}_{1}, \mathrm{~K}_{2}, \mathrm{~K}_{3},\left(\mathrm{~K}_{1} \geqslant \mathrm{~K}_{2} \geqslant \mathrm{~K}_{3}\right)$.

When $K_{1}=K_{2} \geqslant K_{3}$ the ellipsoid is "oblate" and the magnetic fabric defines a foliation. When $K_{1} \geqslant K_{2}$ $=\mathrm{K}_{3}$ the ellipsoid is "prolate" and there is a magnetic lineation.

In unperturbed sediments the magnetic susceptibility is characterized by an oblate ellipsoid with the minimm susceptibility axis, $\mathrm{K}_{3}$, normal to the bedding plane. Any observed magnetic lineation has generally been considered as resulting from the presence of depositional currents (Hamilton and Rees, 1970; Argenton et al., 1975; Elwood, 1979, 1980).

In consolidated sedimentary rocks it has been found that with increasing deformation a prolate or "pencil" structure develops at the end of which the $\mathrm{K}_{2}$ and $K_{3}$ axes form a girdle about the pencil direction defined by a clustering of the $\mathrm{K}_{1}$ axes perpendicular to the maximum principal compressive strain (Borradaile and Tarling, 1981; Kligfield et al., 1981, 1983).

We describe the susceptibility ellipsoid using the ratios $\mathrm{K}_{1} / \mathrm{K}_{2}, \mathrm{~K}_{2} / \mathrm{K}_{3}, \mathrm{~K}_{1} / \mathrm{K}_{3}$ to characterize the lineation, foliation and total anisotropy respectively, and make use of the "anisotropy plots" of $\mathrm{K}_{1} / \mathrm{K}_{2}$ versus $\mathrm{K}_{2} / \mathrm{K}_{3}$ (Hrouda ,1982; Turner and Gough, 1983).

In the great majority of the cases studied here, the susceptibiblity ellipsoid is oblate, with the $\mathrm{K}_{3}$ axis nonmal to the bedding, so that the sedimentary fabric clearly dominates. However a well defined magnetic lineation is also present. In order to investigate the origin, sedimentary or tectonic, of this lineation the results from the different regions are examined separately.

4.2.1. Coastal Range of Taiwan. The magnetic fabric of the three sites of tuffaceous sandstones is characterized by an extremely high scatter of the directions of the three axes of the susceptibility ellipsoid. No preferential orientation is observed for any of them. It is possible that this scatter results from the rather coarse-grained lithology of this formation. Whatever the explanation, no useful information could be obtained from these three sites.

The results obtained at site 12 are reported on Fipure 3 before and after unravelling the slumped beds about the slump axis and bedding correction. The very significant improvement on the grouping of the $\mathrm{K}_{3}$ axes is a good evidence that depositional processes, rather than compaction of the sediments, are responsible for the very near vertical $\mathrm{K}_{3}$ (with respect to the bedding).

At the eight other sites, sampled in marls of Pliocene to Pleistocene age, the $\mathrm{K}_{3}$ axis is nomal to the bedding, showing that the sedimentary fabric is largerly preserved. In addition a well marked lineation is present. Its direction lies between NOOO and $\mathrm{NO40}$ at the different sites. This direction is thus roughly parallel to the general trend of the belt. However, the scatter is too high to ascertain whether the direction of $\mathrm{K}_{1}$ is closer to one or the other of the two structural trends of this region, i.e., that of the Longitudinal Valley or that of the "en echelon" folds.

It should be noted that the sediments have been deposited before folding occurred, so that the existence of the magnetic lineation cannot be 


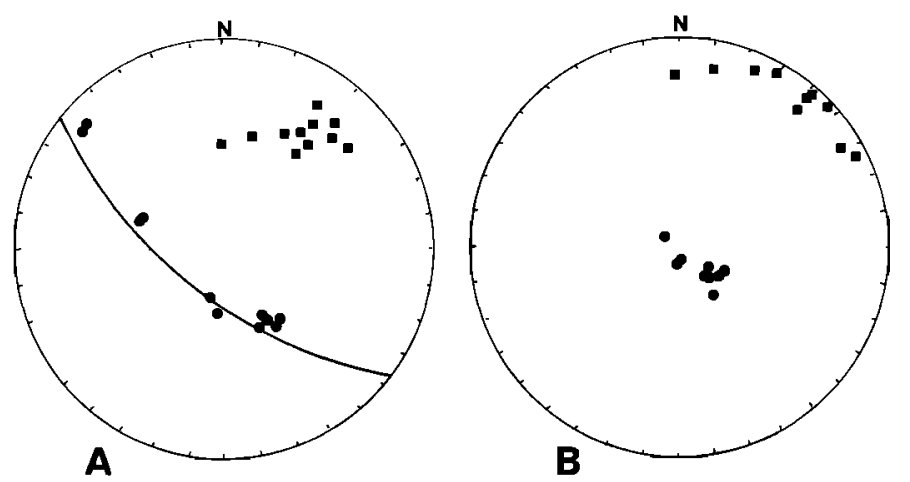

Fig. 3. Stereographic projections (lower hemisphere) of the directions of $\mathrm{K}_{1}$ (squares) and $\mathrm{K}_{3}$ (circles) of site 12 from Taiwan. They are reported (A) before and (B) after unravelling the slump. The plane perpendicular to the axial plane of the slump is also projected.

ascribed to depositional currents channeled by preexisting structures.

4.2.2. Northwestem Greece. The mean orientations of the magnetic lineation for each region of Northwestem Greece are reported in Figure 2.

4.2.2.1. Epirus. In this region all the sites were sampled in the marls of the flysch formations in the three main synclines of Botzara, Dodoni an: Kalentzi (Figure 2). Stratigraphically these sitos range from Lower to Upper Oligocene, with a few sites of Burdigalian age (Kissel et al., 1985a).

The susceptibility values are rather scattered and range from 25 to 1800 (SI units). The degree of anisotropy is generally relatively high, the total anisotropy being of the order of $8 \%$ with no major differences within or between sites. The $\mathrm{K}_{3}$ axes are very closely normal to the bedding, as shown in the two stereographic diagrams of Figure 4. This figure also shows that the tightly grouped $K_{1}$ axes define the same magnetic lineation at both sites whatever the dip of the bedding plane. This is in fact the general direction of the magnetic lineation for all the sites in Epinus, as shown by the plots of Figure 5. In this figure the broken lines indicate the mean directions of the $K_{1}$ axes for the three synclines calculated using a method given by Westphal (1981). The corresponding anisotropy plots indicate that the magnetic fabric is mainly sedimentary. Although the distribution of nonpolar directions does not conform to Fisher's statistics, the cones of $95 \%$ confidence calculated in this way may be used as a rough estimate of the scatter: they range between $5^{\circ}$ and $10^{\circ}$ depending on the site.

The mean direction of $\mathrm{k}_{1}$ is virtually aligned with the axis of the syncline in the three cases. The first phase of folding of the Epinus synclines occurred at the end of the Burdigalian (IGRS-IFP, 1966), so that all the studied samples were deposited long before the syncline was formed. As in Taiwan the presence of the magnetic lineation cannot be an effect of depositional currents.
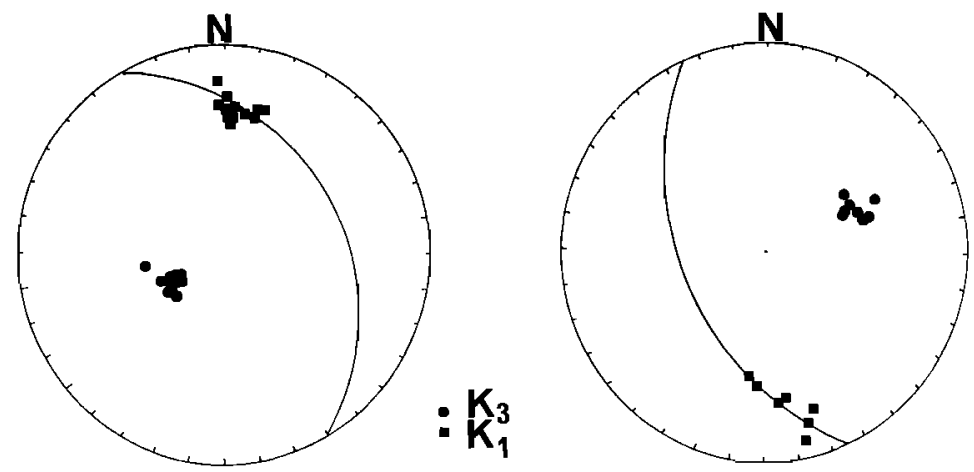

Fig. 4. Stereographic projections on the lower hemisphere of the direction of $\mathrm{K}_{1}$ and $\mathrm{K}_{3}$ of 2 sites from Epirus before bedding correction. The bedding plane is projected and is very different in the two cases. It clearly shows that $\mathrm{K}_{3}$ axis is perpendicular to the bedding plane and that a magnetic lineation exists. 

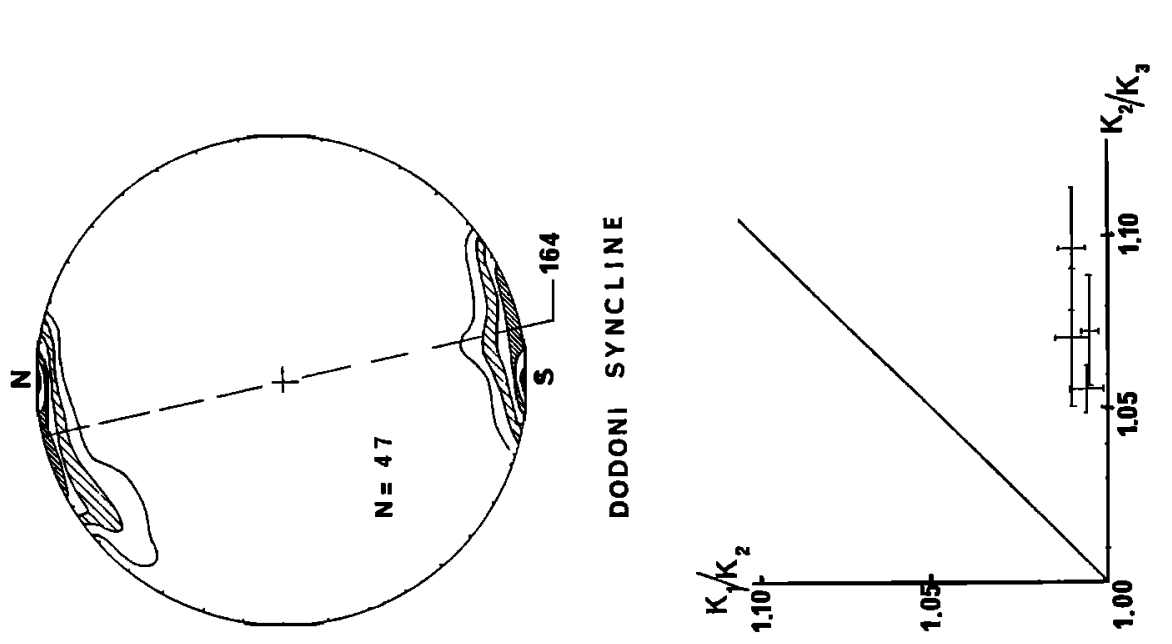

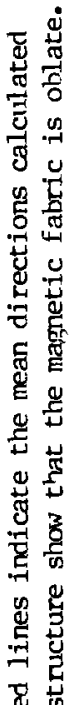
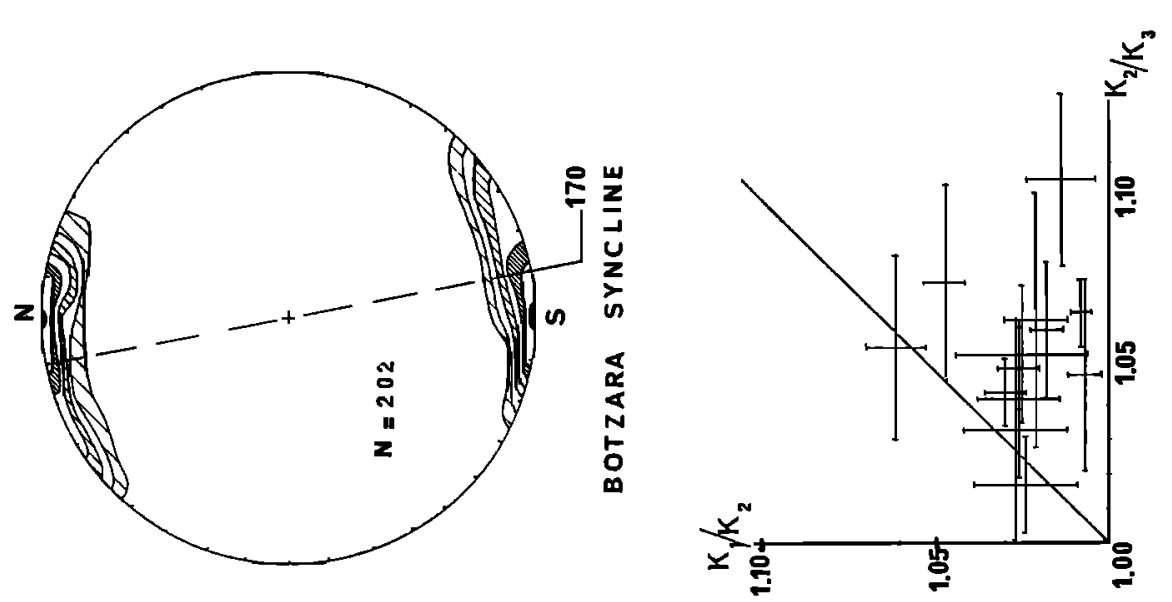

岛

焉

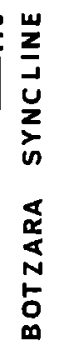

零

踏

돌

营

$\underbrace{3}_{-1}$

号息
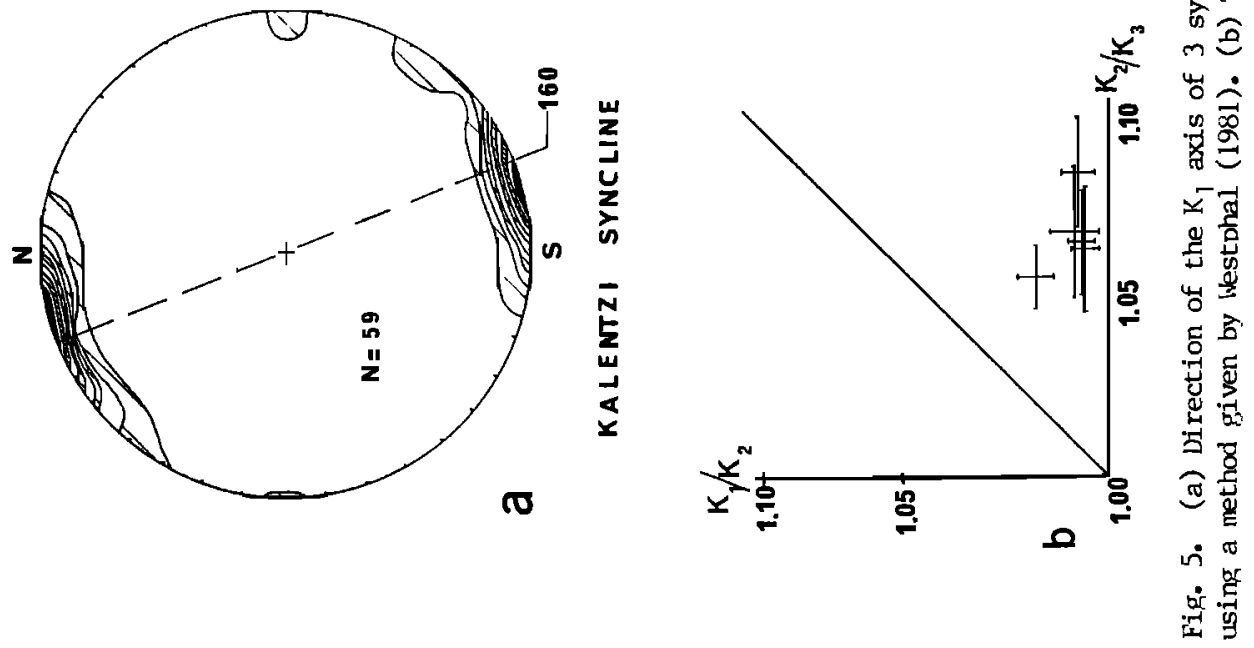


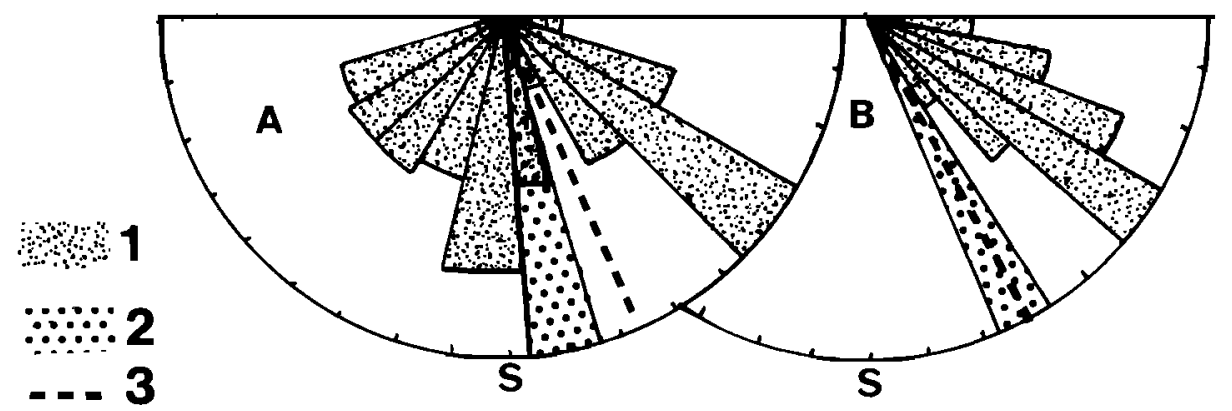

Fig. 6. Distribution of the directions of (1) flute-casts, (2) $\mathrm{K}_{1}$ (calculated using the method described by westphal (1981)) and (3) the axis of the structure for (A) measurements made over a distance of about $10 \mathrm{~km}$ along a road in the Botsara syncline (It must be noticed that in this case two distinct preferential directions of depositional currents were found, one of which does not appear in the magnetic data) and (B) a particular site in Enirus where sandstones and marls formed a sequence of finely altemating beris.

Nevertheless, we have studied the different sedimentary features (flute-casts, lineations, etc.) in order to obtain independently the direction of the depositional currents. These measurements were realized on Oligocene sandstone beds intercalated in the marls used for the magnetic measurements, in the Botzara syncline. Figure 6 presents the results of measurenent of the direction of Flute-casts: (1) over a distance of about $10 \mathrm{~km}$ along the road Vrossina-Kato Vereniki in the Botsara Syncline (126 measurements) and (2) on one particular site where sandstones and marls formed a very long sequence of finely alternating beds (103 measurements).

In the first case the directions of the flute-casts are rather scattered. Nevertheless two distinct preferential directions were obtained: the first one trends $\mathrm{N190}$, the second one N130 while the fold axis is at N155. Both at each single site and on the average the $\mathrm{K}$, direction ( $\mathrm{N170}$ ) is intermediate between the fold axis and the $\mathrm{N} 190$ direction of the current.

In the second case only one direction of the flute-casts was found. This direction is significantly different from that of the $k_{1}$ axis, which is subparallel to the syncline axis. These results thus suggest that the direction of the $\mathrm{K}_{1}$ axis is related more to the fold axis than to the direction of the depositional current.

4.2.2.2. Akarnania. As in Epirus, the different sites from Akamania have been sampled in synclines the axes of which are aligned with the regional trend of the belt, the Pyrgi, the Skoutitsias and the Agrios Yorgos syncline in the south (British Petroleum, 1971).

The values of susceptibility are less scattered than in Epirus and range from 200 to 500 while the total anisotropy is of the order of $6 \%$.

In the first two synclines, the results are very similar to those obtained in Epirus, with the $\mathrm{K}_{3}$ axes normal to the bedding and the magnetic lineation aligned with the axis of the syncline (Figure 7). For the sites in the Agios Yorgos syncline there is no evidence that the tectonic effects might have been larger than in the rest of Akamania. On the contrary the bedding plane has the same strike at all sites with a gentle dip of $8^{\circ}-10^{\circ}$. Nevertheless the directions of the individual $\mathrm{K}_{3}$ axes are more scattered and the individual $\mathrm{K}_{1}$ axes are not systematically contained in the bedding plane. However the projection of the magnetic lineation on this plane has the same direction (N16OE) as in the two other synclines and in Epirus. Also, in the anisotropy plot the $\mathrm{K}_{1} / \mathrm{K}_{2}$ ratio is greater than $\mathrm{K}_{2} / \mathrm{K}_{3}$, suggests an increased tectonic contribution to the magnetic fabric.

4.2.2.3. Ionian Islands. The magnetic fabric of the fomations studied in the three Ionian Islands is largely sedimentary. The susceptibility values are relatively low (100 to 250) and the total anisotropy is of the order of $2 \%$.

Some differences appear between Kephallinia and Zackinthos on one side and Corfu on the other. In the first two islands the susceptibility ellipsoid is generally oblate with the $\mathrm{K}_{3}$ axis not significantly far from the nonnal to the bedding, with the only exception of a site sampled in the marls of the Zackinthos monocline near the village of Maherado. At this site, where more than 80 samples were studied, $\mathrm{K}_{2}$ and $\mathrm{K}_{3}$ are very close in magnitude and form a girdle around the $K_{1}$ axis itself aligned along the axis of the monocline (Figure 8). Visually, however, the sediments do not appear at all deformed or in any way different from the other sites sampled in the same formations which are all characterized by an oblate susceptibility ellipsoid. On the contrary, the bedding has a constant strike and dips about $25^{\circ}$ eastward. It should be noted that the age of the sediments is placed by foraminifera and namoplancton biostratigraphy at about $12 \mathrm{~m} . \mathrm{y}$. (Serravallian-Tortonian boundary) while the monocline 


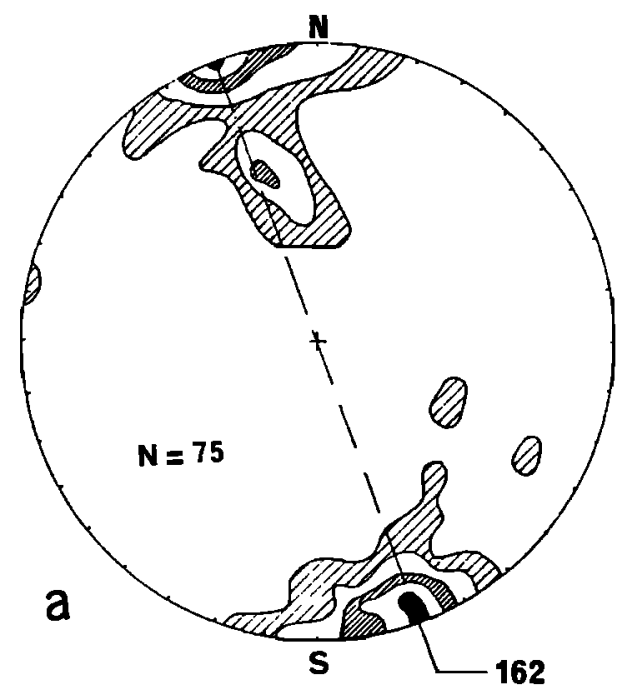

A KARNAN I A

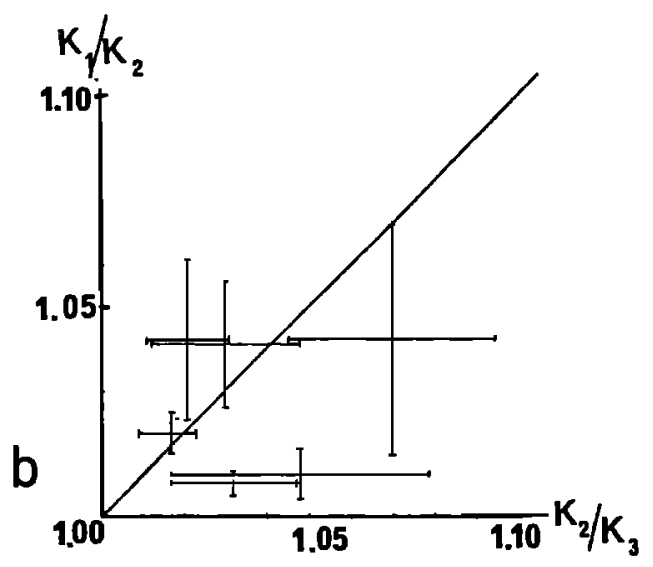

Fig. 7. (a) Distribution of the direction of $\mathrm{K}_{1}$ axis in Akarnania (with the mean direction at N $160 \mathrm{E}$ ) and (b) the "anisotropy plot."

was formed during the Lower Pliocene compressive phase. As in Epirus, folding has taken place long after the deposition, again excluding any channeling ef fect.

At all the other sites in both Zackinthos and Kephallinia a well defined magnetic lineation exists the azimuth of which has the sane direction (N160 E) as the $K_{1}$ axis at Maherado (Fipure 9).

The results obtained in Corfu are somewhat different. As can be seen in Figure 9 there is no definite prefential orientation of the $K_{1}$ axes which are widely scattered in the bedding plane. As there is no correlation between the orientation of $k_{1}$ and that of the local fold axis, this scatter does not result from the fact that the structures are not all aligned along the regional trend. In fact the within-site scatter is higher in Corfu than in the two other islands suggesting that the magnetic fabric is almost entirely sedimentary. However, if two particular sites where the directions are most scattered are not considered, then a magnetic lineation appears whose direction (N 160 E), although more scattered, is identical with that from the two other Ionian Islands.

\section{DISCUSSION AND CONCLUSION}

In contrast with usually held ideas, the above results indicate that even in this kind of almost unconsolidated and visually undeforned sediments the magnetic fabric is not entirely determined by depositional processes. The grouping of the $\mathrm{K}_{3}$ axes in a direction closely perpendicular to the bedding is an indication that the depositional fabric is still marked. But the almost perfect aligmement of the $K_{1}$ axes with the fold axes indicates a tectonic contribution.

Indeed these results are similar to those obtained on weakly deformed consolidated sedimentary rocks (Borradaile and Tarling, 1981; Kligfield et al., $1981,1983)$. In particular the results obtained at Maherado are exactly what has been observed at the end stage of the pencil structure. In most of the other sites the observed tectonic magnetic fabric is not quite as developed: the $K_{1}$ axes are always perpendicular to the direction of maximm shortening but the $\mathrm{K}_{3}$ axes are perpendicular to the bedding and well separated from the $\mathrm{K}_{2}$ axes. We think that this wight represent an even earlier stage of deformation, in agreenent with other recently reported results (Lowrie and Hirt, 1985). This implies that the first effect of deformation is to alion the $K_{1}$ axes perpendicular to the compressive strain and then to scatter $\mathrm{K}_{2}$ and $\mathrm{K}_{3}$ along a girdle.

It is very remarkable that over the entire Northwestern Greece the strain, as inferred by the magnetic anisotropy varies somewhat in amplitude but has a constant direction. It has already been renarked for other regions (Turner and Gough, 1983) that in such cases the small-scale stresses are probably aligned with the corresponding principal strain. The relation of strain to stress is however delicate to derive.

In the Coastal Range of Taiwan, the paleostress directions have been inferred indirectly by an extensive fault population analysis, based on conjugate strike-slip faults and conjugate reverse systems all well developed and numerous in this region (Barrier and Angelier, 1985). Although this analysis is based on strain measurenents, the paleostress direction have been inferred using a simple model of deformation (Carey and Brunier, 1974) subsequently modified (Angelier, 1975; Angelier et al., 1982). At each site the calculated directions of $\sigma_{1}$ are well controlled by the coherence of the fault population.

The magnetic analysis has been carried out on 


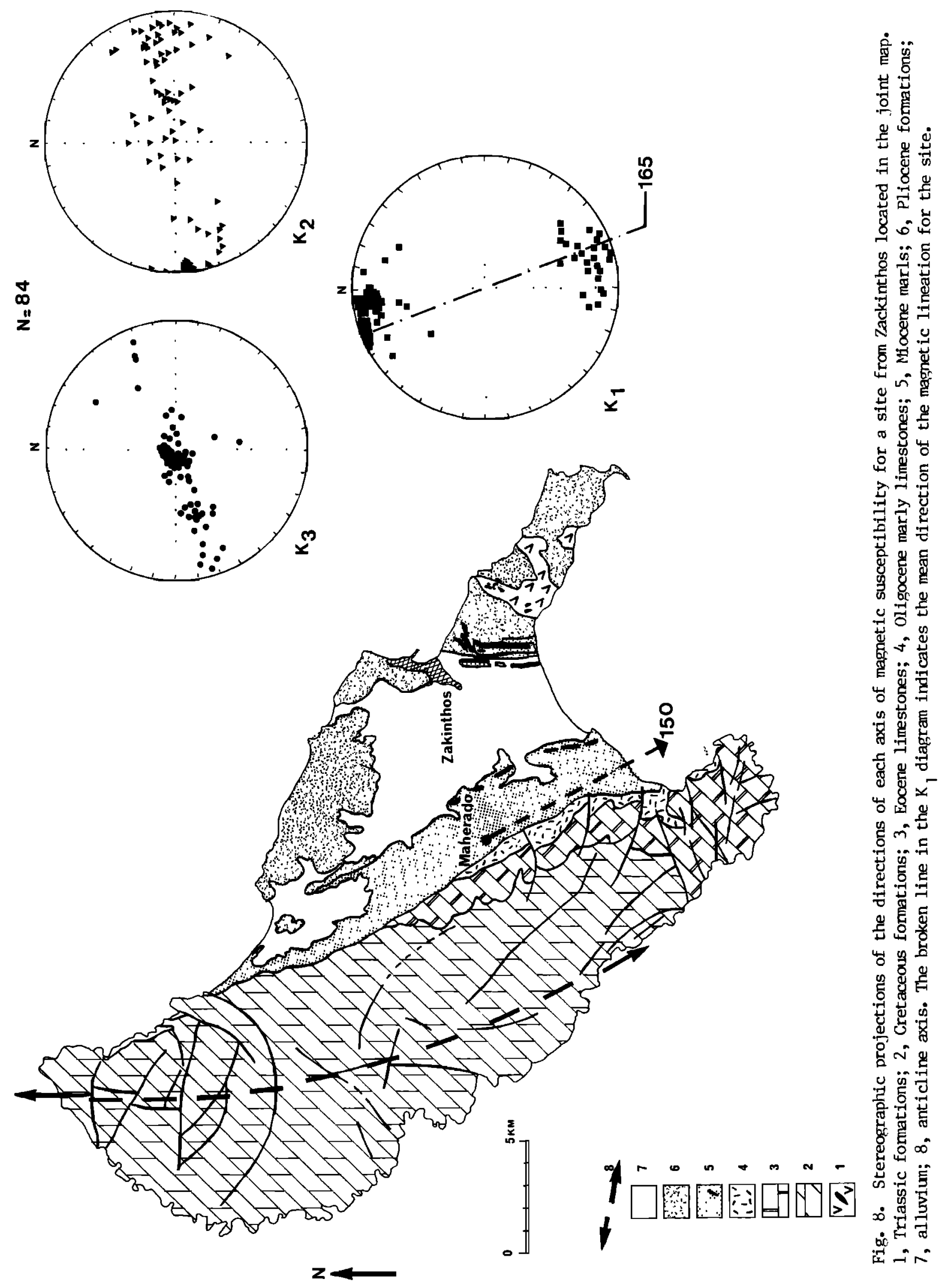



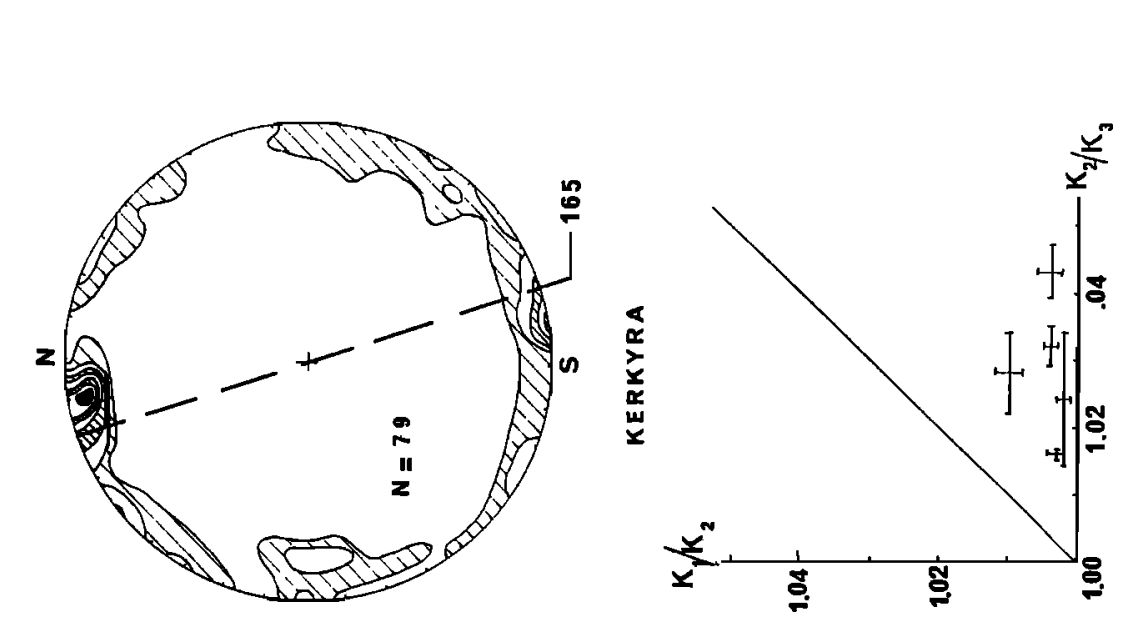

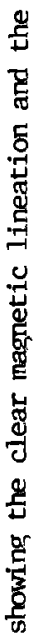
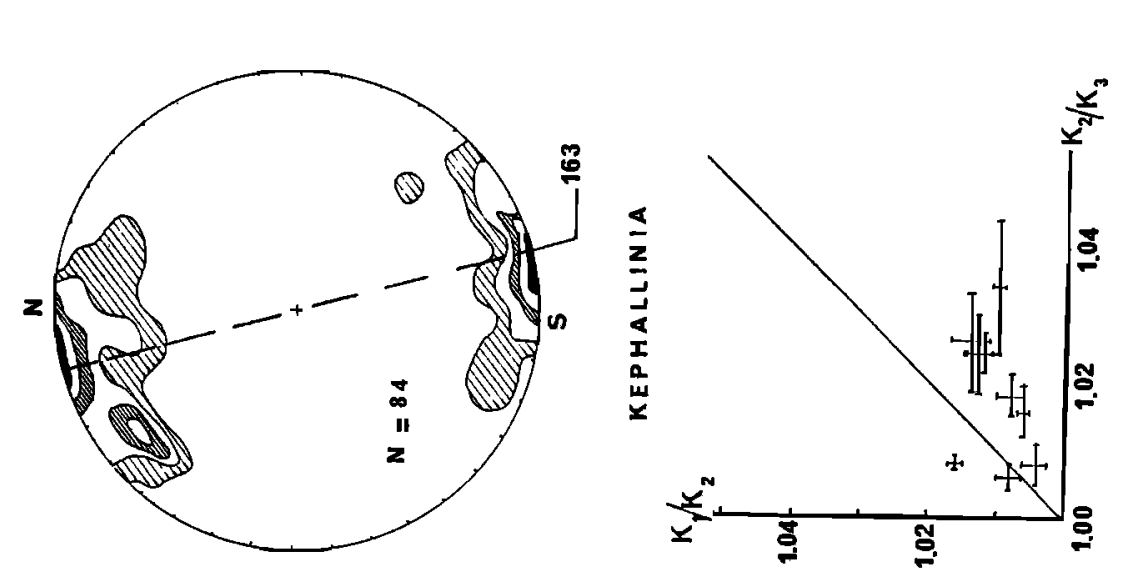

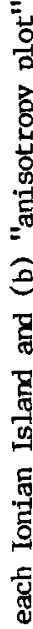
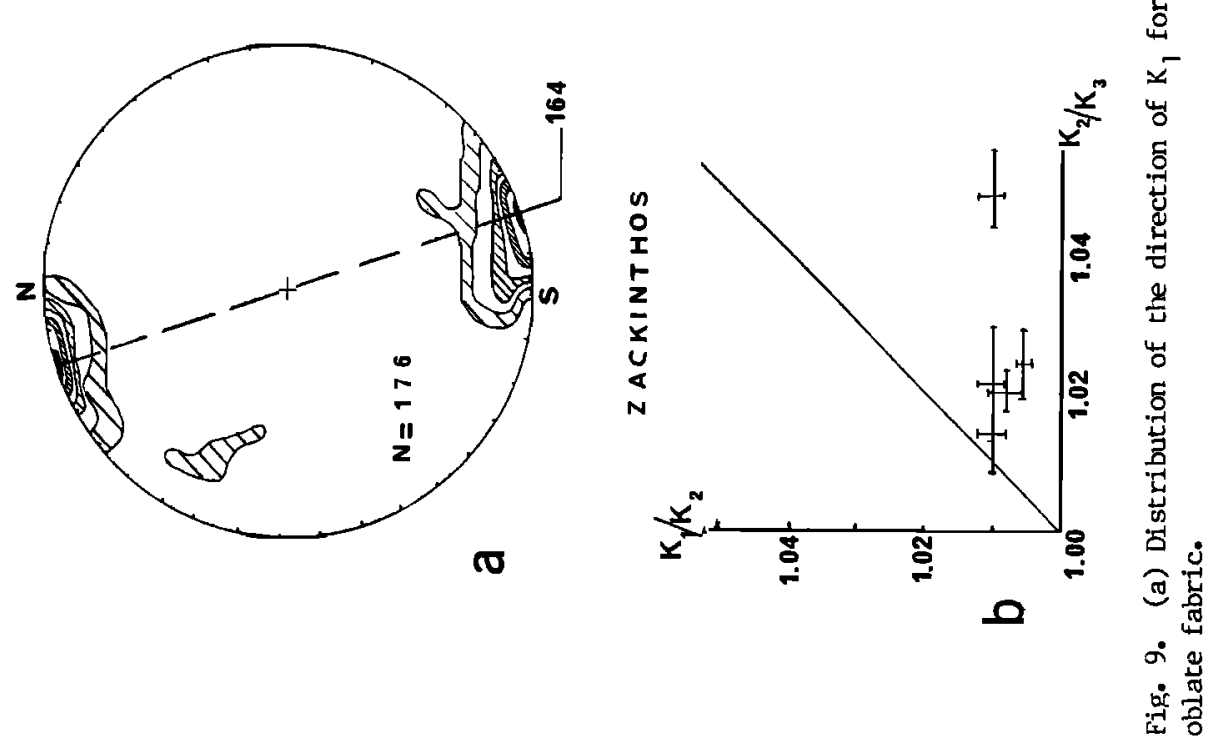
sites where results of fault tectonic analysis had been previously obtained. A comparison of the direction of the magnetic lineation with that of the compressive stress $\sigma_{1}$ has thus been done directly at each site (except for site 'N 10 where no tectonic analysis was available). The results are renorted in Figure 1. In the majority of cases the $k_{1}$ axis is closely perpendicular to the local direction of $\sigma_{1}$. At site $\mathrm{T} V 11$, however, the direction of $\mathrm{K}_{1}$ and of $\sigma_{1}$ are similar. This is the only exception which we have found in all this studv. It must be noticed however that the direction determined at site TW 11 by fault tectonic analysis is itself an exception from a tectonic point of view. It is completely different from all the other determinations and perpendicular to the mean value of the compressive stress for the Coastal Range (Barrier and Angelier, 1985). This anomalous direction might be due to a major overthrust which exists near this site, but does not yield any definite idea about the coincidence of the $\sigma_{1}$ and $K_{1}$ direction.

In Northwestern Greece stresses are known for the present from the focal mecanism solutions of the earthquakes (Ritsema, 1974; McKenzie, 1978) or in situ measurements (Paquin et al., 1984). Both techniques show that the present day direction of the compression is along N065 ,i.e., perpendicular to the general trend of the main structures. The paleostress directions have been inferred using microtectonic analyses in the Ionian islands for the period from Upper Miocene to the present (Mercier et al., 1979). The model of deformation which was used is the one developed by Carey and Brunier (1974), which seems particularly well adapted to the studied region (Mercier, 1976). The paleostress directions determined by this method for the most recent Quaternary coincide with those detemined from in-situ measurements, which is a good indication of the overall validity of the method. The main result of this tectonic analysis is that the regional direction of the compressive stress $\sigma_{1}$ in the Ionian islands has been closely perpendicular to the trend of the main structures since the Upper Miocene (Mercier et al., 1979).

In Greece the tectonic and the magnetic analyses have been conducted independently on distinct sites. We have thus compared the directions of $\sigma_{1}$ and of $k_{1}$ on a regional scale. It can be seen from Figure 2 that in the Ionian islands these two directions are closely perpendicular.

In Epirus and Akarnania no paleostress determinations are available. The magnetic anisotropy, however, has a very consistent direction over the entire studied area. As noted above these structures have not been significantly affected by the more recent tectonic phases documented in the Ionian Islands, so that the consistent directions of $\mathrm{K}_{1}$ over the entire geographical zone and the entire period from Lower Oligocene to the present cannot be ascribed to an overprint due to the most recent tectonic phase. It may then be tentatively suggested that in Epirus and Akamania $\sigma_{1}$ has also been perpendicular to the trend of the Oligo-Miocene structures.

The magnetic anisotrony studies then suggest that in the entire Northwestern Greece (mainland and Ionian Islands) the direction of the compressive stress has been perpendicular to the trend of the major structures since Lower Oligocene.

Recent paleomagnetic results have shown that the entire region has undergone a total clockwise rotation of about $45^{\circ}$ in two main phases of rouphly equal amplitude (Horner and Freeman, 1983; Kissel et al., 1984, 1985a). Since the relative orientation of the compressive stress and the structures has not changed, this implies that the stress field itself has undergone the same clockwise rotation (Kissel et al., 1985b).

As a conclusion it appears that the mapnetic fabrics of these "undeformed" sediments, although largely sedimentary, is partly detemined by tectonic processes. Care must be paid to the structural setting before using the magnetic fabric as a paleocurrent indicator. On the other hand, this fabric may be a useful tool for tectonic study.

Further studies are now needed to investipate, for this kind of sediments, the mechanism of the relation between strain and magnetic fabric for which no informations were obtained here. It would also be interesting to study how the magnetic fabric of sediments is affected by successive compressive stresses of different directions.

Aknowledgments. We wish to thank Prof. Tsai for the constant and active interest for the paleomagnetic studies in Taiwan, F. Heller and J. J. Wagner for their scientific and "technical" help, D. Sorel for his help in the field and discussions, A Hirt for many suggestions to improve the manuscript. Iannis and Katharina Notis warmly welcomed us at Maherado in 7ackinthos, where part of the samiling was done in their garden. S. Guitton, Y. T. Lue, A. Mazaud, S. Sen and J. P. Valet helped with the sampling and with some measurements. The Director of the Institute of Geology and Mining Research (IGM) at Athens kindly provided the necessary permits. The financial support was given by the CNRS-PNEIC, and the INAG-ATP; Sismogénèse, Plis, Failles: Mécanique de la lithosphère. Contribution CFR 766.

\section{REFERENCES}

Angelier, J., Sur l'analyse de mesures recueillies dans des sites faillés: L'utilité d'une confrontation entre les méthodes dynamiques et cinématiques, C. R. Acad. Sci. Paris, 283, 466, 1975.

Angelier, J., E. Barrier, and P. Huchon, Sur les relations entre trajectoires de contrainte et directions de motvement le long d'une frontière 
convergente: Exemple de la subduction hellènique (Grèce) et de la collision Philippines-Eurasie (Taiwan et Japon), C. R. Acad. Sci. Paris, 294, 745-748, 1982.

Argenton, H., C. Bobier, and J. Polveche, La mesure de 1 'anisotropie de susceptibilité mapnétique dans les flyschs: Application à la recherche des directions des paléocourants, Sediment. Geol., 14, 149m-167, 1975.

Barrier, E., Un grand accident actif: La faille de la vallée longitudinale de Taiwan, Rev. Géol. Dyn. Géogr. Phys., 26 (1), 45-60, 1985.

Barrier, E., and J. Angelier, Active collision in Eastern Taiwan: the Coastal Range, Tectonophysics, 125, 39-72, 1986.

British Petroleum, The Geological Results of Petroleum Exploration in Western Greece, Institute for Geology and Subsurface Research, Athens, 1971.

Borradaile, G. J., and D. H. Tarling, The influence of deformation mechanisms on magnetic fabrics in weakly deformed rocks, Tectonophysics, 77, 151-168, 1981.

Brumn, J. H., Etude géologique du Pinde septentrional et de la Macédoine occidentale, Ann. Geol. Pays Hell., 8, 258 pD, 1956.

Carey, E., and B. Brunier, Analyse théorique et numérique d'un modèle mécanique élémentaire appliqué à 1 'étude d'une population de failles, $C_{.}$ R. Acad. Sci. Paris, 279, 891-894, 1974.

Chi, W. R., J. Namson, and J. Suppe, Record of plate interactions in Coastal Range, Eastern Taiwan, Mem. Geol. Soc. China, 4, 155-194, 1981.

Elwood, B. B., Sample shape, and magnetic grain sizes: Two possible controls on the anisotropy of the magnetic susceptibility variability in deep-sea sediments, Earth Planet. Sci. Lett., 43, 309-314, 1979.

E1wood, B. B., Application of the anisotropy of mapnetic susceptibility method as an indicator of bottomwater flow direction, Mar. Geol., 34, M83-M90, 1980.

Hamilton, N. D., and A. I. Rees, The use of magnetic fabric in paleocurrent estimation, in Paleogeophysics edited by $\mathrm{S}$. K. Kuncom, pp 445-464, Academic Orlandos Flag., 1970.

Horner, F., and R. Freonan, Paleanagnetic evidence from pelagic limestones for clockwise rotation of the Ionian Zone, Western Greece, Tectonophysics, 98, 11-27, 1983.

Hrouda, F., Magnetic anisotropy of rocks and its application in Ceology and geophysics, Geophys. Surv., 5, 37-82, 1982.

Institut de Géologie et Recherche du Sous-sol Institut Français du Pétrole, Etude Géologique de 1'Epire (Grèce Nord-Occidentale), 306 pp., Ed Technip, Paris, 1966.

Kissel, C., M. Jamet, and C. Laj, Palaeomagnetic evidence of Miocene and Pliocene rotational deformations of the Aegean Area, The Ceological Evolution of the Eastem Mediterranean, edited by
J. E. Dixon and A. H. F. Robertson, Spec. publ. Geol. Soc. London, 17, 669-679, 1984.

Kissel, C., C. Laj, and C. Muller, Tertiary geodynamical evolution of Nortiwestem Greece: Paleomagnetic results, Earth Planet. Sci. Lett., 72, 190-204, 1985a.

Kisse1, C., D. Sorel, M. Jamet, and C. Laj, Stress field rotation in Northwestern Greece since Upper Oligocene (abstract), Terra Cognita, 5, 171, 1985b. Kligfield, R., W. H. Owens, and W. Lowrie, Magnetic susceptibility anisotropy, strain, and progressive deformation in Permian sediments from the Maritime Alps, Earth Planet. Sci. Lett., 55, 181-189, 1981.

Kligfield, R., W. Lowrie, A. Hirt, and A. W. B. Siddans, Effect of progressive deformation on remanent magnetization of Permian redbeds from the Alpes Maritimes (France), Tectonophysics, 97, $59-85,1983$.

Laj, C., M. Jamet, D. Sorel, and J.P. Valente, First paleomagnetic results from Mio-Pliocene series of the Hellenic sedimentary arc, Tectonophysics, 86 , 45 -67, 1982.

Lowrie, W. and A. M. Hirt, Compactional and tectonic magnetic fabrics in the Scaglia Rossa limestone (abstract), 5th IAGA Conf., 1, 207, 1985.

Mckenzie, D., -Active tectonics of the Alpine Himalayan belt: the Aegean Sea and surrounding regions, Geophys. J. R. Astr. Soc., 55, 217-254, 1978.

Mercier, J. L., La néotectonique, ses méthodes et ses buts. In exemple: L'arc égéen (Méditerranée orientale), Rev. Géol. Dyn. Géogr. Phys., 4, $323-346,1976$.

Mercier, J. I, N. Delibassis, A. Gauthier, J. J. Jarrige, F. Lemeille, H. Philipp, M. Sebrier, and D. Sorel, La néotectonique de 1 'arc égéen, Rev. Géol. Dyn. Géogr. Phys., 21, 67-92, 1979.

Paquin, C., J. Bloyer, and C. Angelidis, Tectonic stresses on the boundary of the Aegean domain: "In situ" measurements by overcoring, Tectonophysics, 110, 145-150, 1984.

Rathore, J. S., The magnetic fabrics of some slates fron the Borrowdale volcanic group in the English Lake District and their correlation with strain, Tectonophysics, 67, 207-220, 1980.

Rees, A. I., The effect of water currents on the magnetic remanence and anisotropy of susceptibility of some sediments, Geophys. J. R. Astron. Soc., 5, 235-251, 1965.

Ritsema, A. R., The earthquake mechanisns of the Balkan region, Sci. Rep. 74-4, 36 pp., R. Neth. Meteorol. Inst., 1974.

Rochette, P., and P. Vialon, Development of planar and linear fabrics in Dauphinois shales and slates (french Alps) studied by magnetic anisotropy and its mineralogical control, J. Struct. Geol., 6, 33-38, 1984.

Suppe, J., Mechanics of mountain building and metamorphism in Taiwan, Mem. Geol. Soc. China, 4, $67-89,1981$. 
Turner, G. M., and D. I. Gough, Magnetic fabric, strain and paleostress in the Canadian Rocky Inountains, Tectonophysics, 96, 311-330, 1983.

Veitch, R. J., I. G. Hedley, and J. J. Wagner, Nagnetic Anisotropy delineator calibration error, Ceophys. J. R. Astron. Soc., 75, 407-409, 1983. Westphal, M., Analyse statistique de directions non orientées, Pure Appli. Ceoghys., 119, 80-86, 1981.

E. Barrier, C. Kissel, and C. Laj, Centre des
Faibles Radioactivités, Laboratoire mixte CNRS/CFA, Domaine du CNRS, 91190 Gif-sur-Yvette, France.

T. Q. Lee, Institute of Earth Sciences, Academia Sinica, Taipei, Taiwan, Republic of China.

(Received May 15, 1985;

revised Decenber 20, 1985;

accepted February 3, 1986.) 